\title{
Budgeting Slack, Social Pressure, and Autonomous Behavior in Experiment Relationship
}

\author{
Annisa Ilma Hartikasari ${ }^{1}$, Ira Hapsari ${ }^{2}$ \\ \{aihartikasari@gmail.com ${ }^{1}$, ira.dirgantara@gmail.com² \\ Faculty of Economics and Business, Universitas Muhammadiyah Purwokerto
}

\begin{abstract}
The purpose of this study is to examine the effect of improper social pressure on business unit controller's inclination to create budgetary slack in the setting of organizational justice in the form of distributive and procedural justice. The creation of budgetary slack in this study is related to produce lower ROI target compared with actual ROI target that can be achieved by business unit. Furthermore, this study also examines the impact of Autonomous Motivation on the causality of social pressure, organizational justice, and the creation of budgetary slack. The experimental method is used in this study with $2 \times 2$ between subject design factorial. The participants were 152 postgraduate accounting and management students from two large private universities in Indonesia. Hypothesis testing is done using two-way Anova and Ancova. The results show several things. First, controller business unit under high social pressure have a greater tendency to create budgetary slack. Second, procedural justice is more effective than distributive justice at reducing budgetary slack creation by controller business unit. Third, controller under conditions of low social pressure and distributive justice will still tend to create budgetary slack and on the contrary, procedural justice will decrease the tendency of budgetary slack creation even though there is a high social pressure. Fourth, after controlling Autonomous Motivation, there is still interaction effect between social pressure and organizational justice on the creation of budgetary slack by controller business unit.
\end{abstract}

Keywords: Budgetary Slack, Social Pressure, Organizational Justice, Distributive Justice, Procedural Justice, Autonomous Motivation.

\section{Introduction}

Business unit controllers are required to support business unit managers in making strategic and operational decisions. The role generates strong personal relationships between controllers and managers[1]. Strong attachment to managers and business units causes controllers to be more willing to comply with managers' orders despite contradicting professional norms. The willingness is based on the belief that what managers instruct is a way for a business unit to make a profit.

Research shows that business unit controllers deliberately make mistakes in financial reporting, resulting in budgetary slack caused by pressure from business unit[2] [3]. The relationship and involvement of business unit controllers in the decision making process makes social pressures difficult to eliminate[4]. The ability of the controller to avoid the social pressure that leads to deliberate false financial reporting is then recognized as an important professional competence to have.

The influence of social pressures on the creation of budgetary slack, especially those performed by business unit controllers, will be the first point in this study. As [3] have shown, business unit controllers who are actively involved in their business unit decision-making 
processes tend to create budgetary slack while accepting pressure from managers to do so. In Indonesia alone, research on social pressure related to budgetary slack has been studied but the type used is only obedience pressure and the results are still varied. Meanwhile, research using three types of social pressure in Indonesia has been done by [5] but related to judgment auditor.

In their research, [3] also found that Autonomous Motivation nature in self-controlled business units proved to strengthen the influence of social pressure on the decision to do budgetary slack. Meanwhile, [6] and [7] found that employees with high Autonomous Motivation were more likely to commit unethical acts such as financial manipulation and unproductive work.

Autonomous Motivation will be treated as a covariate in this study. This is because accountants are generally shown to have no high Autonomous Motivation nature. Nevertheless, some accountants possessing such traits have been shown to be more inclined to deviate from professional ethics [8]. For that, it will be tested whether Autonomous Motivation is true to the relationship of social pressures and budgetary slack.

As the development of [3] research, the researcher adds organizational justice distinguished to distributive justice and procedural justice as an important second point to be tested in relation to social pressures. Organizational justice has been proven in many previous studies as a factor that negatively affects accounting irregularities and business ethics. [9] found that distributive and procedural justice enhances trust and commitment of managers' budget goals that lead to reduced tendency to create budgetary slack. [6] prove that a fair budgeting system will reduce unethical behavior and managers who feel that the budgeting system is being done fairly will be less likely to create budgetary slack and manipulate financial data.

Procedural justice itself has a negative influence on the tendency to create budgetary slack [10]. Procedural justice is also shown to reduce a manager's personal interests, indicating that someone is willing to sacrifice personal interests for the achievement of organizational goals [11]. While distributive justice was proven to reduce the creation of budgetary slack by managers despite the presence of information asymmetry [12]. However, [13] found in his research that distributive justice would increase the unethical behavior of subordinates lying to superiors.

Based on the explanation of motivation and research gaps in the previous section, this study aims to examine the effect of social pressure and organizational justice on the creation of budgetary slack by business unit controllers. Furthermore, this study will investigate the relations of interaction between social pressure and organizational justice towards the creation of budgetary slack by business unit controllers. In addition, Autonomous Motivation's influence on the interaction between social pressure and organizational justice towards the creation of budgetary slack will be examined.

The test results indicate the influence of social pressure on the creation of budgetary slack by business unit controllers. The results are expected to contribute to a stream of research that wants to know the impact of social pressures on the critical decision-making of a business unit controller. The study also found that organizational justice can reduce the influence of social pressures even though procedural justice is more effective in suppressing the creation of budgetary slack than distributive justice. This result will add insight into the interaction between social pressure and organizational justice regarding individual behavior when faced with ethical dilemmas in decision-making processes. The findings also contribute to the practice by providing input for organizations to be more careful in designing participatory 
budgeting processes and reward systems for employees to create appropriate organizational justice.

\subsection{Social Relations Relationships and Budgetary Slack}

Social pressure has been used in previous studies to predict individual behavior when making a formal decision. Social pressure that has been studied previously can be in the form of positive urges resulting in useful and beneficial decisions [14]. Social pressures can also be in the form of negative pressure or inappropriate orders resulting in adverse decisions. Initial studies on social pressures, one of which was carried out by [16] [17] [18] who examined obedience pressure and produced a classical paradigm of obedience to a party with higher authority. The paradigm explains that an individual will be willing to behave in a deviant manner from his or her beliefs, values and beliefs by accepting the control of another individual with a higher authority.

Furthermore, it is argued that deviant behavior due to pressure from a mre authoritative party is caused by changes in individual psychology from the autonomous stage to the agentic stage called agentic shift. An individual is at an autonomous stage when he behaves as he wishes and is responsible for his own actions. Individuals are then said to move at the agentic stage when the action is aimed at fulfilling the wishes of figures considered to have high authority. This change occurs because of the belief that more authoritative parties have the right to ask for the absolute [19].

The paradigm of obedience pressure is then supported by the findings of [2]. Found in his research, nearly half of the financial managers participated in the creation of budgetary slack when under pressure from superiors. Nevertheless, the managers are actually aware that they are doing irresponsible acts and know that budgetary slack is actually unfair and contrary to their duty. Obedience pressure has also been proven to positively influence the individual's tendency to create budgetary slack depending on the ethical position of each individual [20] $[1]$.

Meanwhile, [21] argue that social pressure leads to conformance, that is the individual's desire to avoid the negative consequences of acting inconsistent with group desires or disloyal to someone with a higher authority position. [22], argues that an individual will make decisions that reflect on what his group has agreed upon, even if the agreement contains errors. This tendency can be explained by social identity theory which states that being part of a group will increase the individual's identification in the group and follow what the common belief is.

[3] then examine the creation of budgetary slack because of the influence of social pressure that consists of obedience pressure, conformity pressure, and compliance pressure. The results revealed that business unit controllers involved in the decision-making process would be more vulnerable to succumb to the pressing social pressures of budgetary slack. These results confirm that an individual's behavior may be affected by the group in which the individual becomes part of it.

Based on the findings of previous research, hypotheses are proposed that business unit controllers who receive high social pressure from their employers, peers, or others will be more likely to create budgetary slack because they feel they have to fulfill the wishes and rights of their superiors. Business unit controllers will more easily give up to social pressures because they feel they have an obligation to behave in accordance with their group so they do not want to make decisions that are not in accordance with the group's beliefs. The actions taken by the controller when making decisions become based on the responsibility to fulfill orders from others not because of their own will. The hypothesis is then expressed as follows. 
H1: High social pressure will result in business unit controllers more likely to create budgetary slack than when there is low social pressure.

\subsection{The Relations between Organizational Justice and Budgetary Slack}

In this research, distributive justice and procedural justice are predicted to have a different impact on the tendency of budgetary slack creation. In accordance with the theory of organizational justice, [23] states that employees' assessment about the fairness of the actual amount of resources distributed to them (distributive justice) is related to the economic exchange relations between employees and organizations, whereas whether resource allocation is judged fair or not (procedural justice) is related to the relations of social exchange (noneconomic).

Previous research has shown a link between procedural justice and social exchange. When processes and procedures implemented by the organization are perceived as fair by employees, positive consequences such as increased job satisfaction and performance, increased willingness to act in accordance with the interests and objectives of the organization, decreased tendency to create budgetary slack and increased organizational citizenship behavior [24] [25] [10].

[25] reported survey results from managers at manufacturing companies. They found that performance evaluation based on budget targets will lead to job satisfaction and improve performance when the evaluation procedure is fair. Explained in this study that fair procedures allow employees to get what they want. Employees who get their wishes will feel satisfied and work better than employees who do not get what they want.

[10] examined the effect of procedural justice mediation on the relationship between ethical work climate, the effectiveness of budgetary control, and the tendency of budgetary slack creation. Subjects are managers working in private companies. It was found that the ethical work climate and the effectiveness of budgetary control had a negative effect on the budgetary slack creation trends when managers had a perception of equity in all resource allocation processes.

[22] argues that the theory of social exchange underlies the influence of procedural justice mediators between participation in decision-making and organizational citizenship behavior. The relationship of social exchange is based on the employee's belief that the organization will repay the obligations that have been made in the future. If in the decision-making process the employee believes in procedural justice, the employee's will display good organizational behavior in the hope of a retaliation in the future. The findings in his research mention that procedural nursing will mediate influence of participation in decision making to organizational citizenship behavior.

[13] found that distributive justice resulted in participants in his research to lie and commit theft for his superiors. Based on the theory of social exchange, if a person or group where someone is benefiting from the work done by another party, then the person must repay the benefits received by giving advantage to the other party.

H2: Business unit controllers who get organizational justice in the form of procedural justice will be less likely to create budgetary slacks than if they get organizational justice in the form of distributive justice.

\subsection{Interaction between Social Pressure and Organizational Justice}

Organizational justice theory from the outset has made a distinction between distributive justice and procedural justice even though previous research has found that both types of 
justice have the same impact on behavior in the budgeting process, bilateral trade agreements, transfer pricing, income tax reporting, and so on. In the context of budgeting, organizational justice is expected to have a negative effect on the creation of budgetary slack because slack in the target or budget report is considered as a result of dysfunctional behavior that can impede performance [26].As in his research, [12] revealed that budgetary slack that appears in the budget target will be lower if managers feel the existence of organizational justice. [9] found that distributive and procedural justice enhances the trust and commitment of managers to budgetary objectives, leading to a reduction in the tendency to create budgetary slack. The findings of both studies provide support that organizational justice is believed to mitigate budgetary slack. Thus, the hypothesis is stated as follows.

H3a: There is an interaction between social pressure and organizational justice in influencing the creation of budgetary slack by business unit controllers.

H3b: Business unit controllers have a greater tendency to create budgetary slack on the condition of organizational justice in the form of distributive justice than in the condition of organizational justice in the form of procedural justice when receiving high or low social pressures.

1.4 The Influence of Autonomous Motivation on Social Pressure, Organizational Justice, and Budgetary Slack

Social pressure from business unit managers to create budgetary slack threatens the control and freedom of business unit controllers' professionals so that it can generate reactance. The low Autonomous Motivation controller involved in management will usually be more emotionally attached and act on the group's behalf. Nevertheless, social pressure will be felt by controllers with lower Autonomous Motivation as a violation of professional beliefs and regulations resulting in reactance reactions by refusing budgetary slack.

Unlike the controllers that have high Autonomous Motivation. Involvement in management is perceived as an opportunity to gain personal benefits from the outcomes generated through the budgeting process. The opportunistic nature and calculations that arise when composing budgets cause controllers with high Autonomous Motivation to be more vulnerable to approve orders for budgetary slack even though it is contrary to ethical professionalism, but on the condition that a clear personal gain is to be obtained [27].The personal gain obtained by the controller is the outcome as a result of drafting the budget proposal because of his/her involvement in management. The outcomes gained on the basis of the contributions made are the concept of distributive justice. It can be argued that with the existence of distributive justice, it would increase the approval of budgetary slack creation for controllers with high Autonomous Motivation involved in management as it gets pressure from business unit managers. Based on the description, the proposed hypothesis is as follows.

H4: By controlling Autonomous Motivation, social pressures and organizational justice still affect the creation of budgetary slack by business unit controllers.

\section{Method}

\subsection{Research Design and Subject}

Factorial design is used in this study because it can test the influence of more than one independent variable simultaneously. The used factorial design is $2 \times 2$ between two factors: 
social pressure (high social pressure and low social pressure) and organizational justice (distributive justice and procedural justice). Each participant will be randomly assigned one manipulation of four manipulations.

Participants in this study are graduate students of accounting and management at the University of General Soedirman and Diponegoro University. Students who are subjected to research are students who have taken and passed the course of Managerial Accounting and/or Financial Management. The total number of participants is 165 students. A total of 11 participants did not pass the manipulation check and 2 participants did not fill the task in the instrument correctly. Thus, participants whose data can be taken for analysis amounted to 152 .

The experimental instrument provided to the participants is an adaptation of [3] processes and instruments but with some development to adjust the current research conditions. Prior to experiments, the research instrument was first tested through a pilot test of 93 graduate students with the primary goal of knowing whether the experimental material was well understood.

\subsection{Experimental Procedure}

Students as research subjects participate in the classroom before or after the lecture process is completed. They are given the option of not following the experiment if they do not want or have other obstacles so that all participants can follow the experiment voluntarily. Before the process, the experimenter's assistant will distribute a package of instruments from the four packages. The division is done randomly so that each participant receives a different case scenario according to the condition of treatment provided and it is expected that each treatment instrument package is divided in equal amount. Each instrument package consists of one case scenario and four assignments: (1) budgetary slack assessment; (2) check manipulation; (3) Autonomous Motivation questionnaire; (4) quiz with prizes. At the beginning of doing the instrument, experimenter prohibits participants from communicating with each other during the experimental process. Experimenter also emphasizes that participants should follow the instructions given well and orderly.

Told in a case scenario about a business unit controller who must face a dilemmatic situation. The controller is forced to show lower business unit performance in the budget proposal. Manipulation of budget proposals is done to increase the likelihood of getting a bonus due to the achievement of budget targets. The business unit where the controller works has just changed its strategy and this change is not working well, causing an inadequacy of ROI in the previous year. The target ROI for this year is not expected to be met. When a business unit management team meeting takes place to make the next year's budget proposal, the general manager of the business unit proposes that the ROI target be made lower than in previous years. The target ROI that will be listed in the proposed budget is made only for $11 \%$ to be easily achieved so that the business unit does not fail to achieve the budget target and the management team also does not lose the bonus. The business unit controller is in charge of realizing a budget proposal with an unrealistic ROI target.

After reading the case scenario, participants will be asked to assess the likelihood that the controller will approve and realize the proposed budget proposal. Participants were then required to fill out a questionnaire containing five questions. These questions are the researchers' way of checking for manipulations intended to see if participants really understand the case according to the conditions of treatment provided.

The next process, the researcher will distribute the questionnaire to be filled by the participants to see the level of Autonomous Motivation tendencies in each participant. Participants will read 20 statements with measurements using a 5-point Likert scale. After 
that, participants do the quiz questions based on a previously read case scenario. Participants who successfully do the right work are entitled to be included in the draw prize to be drawn at the end of the session. In the final stages, participants will be asked to fill in demographic data such as name, gender, age, work experience and others.

\subsection{Operational Definition and Variable Measurement}

Budgetary slack is defined as a performance target that is deliberately made lower than expected [28]. The budget gap is measured by questioning the subject of the trend of business unit controllers in the case scenario, whether to keep budget targets that contain budgetary slack or not. Questions are responded by the subject by giving an assessment in percentage form starting from $0 \%$ (sure not going to do) to $100 \%$ (sure will do).

Social pressure is defined according to [21] as pressure in the form of demand strictly expressed by the individual at various levels (compliance pressure), pressure derived from the superior or command of a person with greater authority (obedience pressure), and pressure exists in a group and comes from a peer (conformity pressure). Social pressures are manipulated into two categories (high and low). Organizational justice is the perception of an employee about the fairness of the actions and management decisions of the organization [29] [30]. Organizational justice is manipulated into two categories (distributive justice and procedural justice).

Autonomous Motivation refers to the ability of individuals to take everything more into account and use others for their own benefit [31]. Autonomous Motivation was measured by a Autonomous Motivation IV scale questionnaire developed by [32] and consisted of 20 items. Each item is scored using a five-point Likert scale $(1=$ "Strongly disagree" to $5=$ "Strongly agree").

\section{Result And Discussion}

The data were analyzed using Two Way Anova to show the influence of each variable to the dependent variable. Table 1 shows the results of Anova's two-way analysis of tests of between-subjects effects.

Table 1. Anova Test Results

\begin{tabular}{lrrrrr}
\hline \multicolumn{1}{c}{ Source } & $\begin{array}{c}\text { Type III Sum } \\
\text { of Squares }\end{array}$ & \multicolumn{1}{c}{ df } & \multicolumn{1}{c}{$\begin{array}{c}\text { Mean } \\
\text { Square }\end{array}$} & \multicolumn{1}{c}{ F } & Sig. \\
\hline Corrected Model $^{\text {a }}$ & 58112,637 & 3 & 19370,879 & 152,780 & 0,000 \\
Intercept & 441808,809 & 1 & 441808,809 & 3484,588 & 0,000 \\
SP & 816,821 & 1 & 816,821 & 6,442 & 0,012 \\
OJ & 56798,283 & 1 & 56798,283 & 447,973 & 0,000 \\
SP*OJ & 531,295 & 1 & 531,295 & 4,190 & 0,042 \\
Error & 18764,830 & 148 & 126,789 & & \\
Total & 527375,000 & 152 & & & \\
\hline Corrected Total & 76877,467 & 151 & & \\
\multicolumn{5}{c}{ A. R. Squared =0,756 (Adjusted R. Squared = 0,751) } \\
\multicolumn{6}{c}{ Annotation: SP (Social Pressure) and OJ (Organizational Justice) }
\end{tabular}


Hypothesis 1 predicts the tendency to create budget independence will be greater if there is high social pressure. Hypothesis testing uses two ways Anova. Shown in Table 1, the main influence of social pressure on budget clearances indicates significance $(F=6.442$ and $p=$ $0.012<0.05)$. Hence, Hypothesis 1 is supported.

Hypothesis 2 states that the tendency to create budgetary slack will be greater in the condition of organizational justice in the form of distributive justice than in the case of organizational justice in the form of procedural justice. It is shown in Table 1 that the main effect of organizational justice on budgetary slack indicates significance $(F=447.973$ and $\mathrm{p}=$ $0,000<0.01)$. Hence, Hypothesis 2 is supported.

Hypothesis $3 \mathrm{a}$ predicts there will be an influence of interaction between social pressure and organizational justice factors on the creation of budgetary slack. Table 1 presents the results of two-way ANOVA test in the form of test of between subject-analysis of variance. The test results show that there is significance of main effect of social pressure $(F=6,442 ; p=$ $0,015)$ and organizational justice $(F=447,973 ; p=0,000)$. The result of interaction effect test between social pressure and organizational justice showed significant value $(F=4,426 ; p=$ 0,037 ) at 0,05 . Hence, Hypothesis $3 \mathbf{a}$ is supported.

The interaction between high social pressure and distributive justice resulted in an average of the greatest tendency to create budgetary slack, which is 73.72. The interaction between high social pressure and procedural justice resulted in an average of the creation of budgetary slack of participants at 38.78. The interaction between low social pressure and distributive justice resulted in an average tendency of creating a budgetary slack of participants at 73.08. The interaction between low social pressure and procedural justice resulted in the average of the least budgetary slack creation tendency at 30.41 . Hence, Hypothesis $3 \mathbf{b}$ is supported.

Hypothesis 4 states that after control on Autonomous Motivationis done, the influence of social pressure interaction and organizational justice on budgetary slack creation by business unit controllers will still persist. To test the hypothesis, a two-way Ancova test was performed which showed the results in Table 3. The test results showed that Autonomous Motivation has no significant effect on the creation of budgetary slack $(F=0.718 ; p=0.398)$. Nevertheless, the interaction between social pressure and organizational justice has a significant value $(\mathrm{F}=$ 6,$317 ; \mathrm{p}=0.013$ ) despite the control on Autonomous Motivation variables is already done. Thus, Hypothesis 4 is supported.

Table 2. Descriptive Statistics

\begin{tabular}{|c|c|c|c|c|}
\hline & & \multicolumn{3}{|c|}{ Organizational Justice } \\
\hline & & Distributive Justice & Procedural Justice & Total \\
\hline \multirow{3}{*}{ 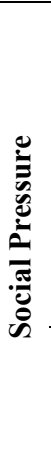 } & $\begin{array}{l}\text { High Social } \\
\text { Pressure }\end{array}$ & $\begin{array}{c}\text { Grup 1 } \\
(\mathrm{N}=39) \\
\text { Mean }=73,72 \\
\text { Std. }=9,44\end{array}$ & $\begin{array}{c}\text { Grup 2 } \\
(\mathrm{N}=37) \\
\text { Mean }=38,78 \\
\text { Std. }=13,40\end{array}$ & $\begin{array}{c}\mathrm{N}=76 \\
\text { Mean }=56,71 \\
\text { Std. }=20,98\end{array}$ \\
\hline & $\begin{array}{l}\text { Low Social } \\
\text { Pressure }\end{array}$ & $\begin{array}{c}\text { Grup 3 } \\
(\mathrm{N}=39) \\
\text { Mean }=72,82 \\
\text { Std. }=14,18 \\
\end{array}$ & $\begin{array}{c}\text { Grup } 4 \\
(\mathrm{~N}=37) \\
\text { Mean }=30,41 \\
\text { Std. }=5,94\end{array}$ & $\begin{array}{c}\mathrm{N}=76 \\
\text { Mean }=52,17 \\
\text { Std. }=23,97\end{array}$ \\
\hline & Total & $\begin{array}{c}\mathrm{N}=78 \\
\text { Mean }=73,27 \\
\text { Std. }=11,97 \\
\end{array}$ & $\begin{array}{c}\mathrm{N}=74 \\
\text { Mean }=34,59 \\
\text { Std. }=11,13 \\
\end{array}$ & $\begin{array}{c}\mathrm{N}=152 \\
\text { Mean }=54,44 \\
\text { Std. }=22,56\end{array}$ \\
\hline
\end{tabular}


Table 3. Two-Way Ancova Test Results with Autonomous Motivation

\begin{tabular}{lrrrrr}
\hline \multicolumn{1}{c}{ Source } & $\begin{array}{c}\text { Type III Sum } \\
\text { of Squares }\end{array}$ & df & \multicolumn{1}{c}{$\begin{array}{c}\text { Mean } \\
\text { Square }\end{array}$} & \multicolumn{1}{c}{ F } & Sig. \\
\hline Corrected Model $^{\text {a }}$ & 58171,966 & 4 & 14542,992 & 114,288 & 0,000 \\
Intercept & 8753,734 & 1 & 8753,734 & 68,793 & 0,000 \\
AM & 59,329 & & 59,329 & 0,466 & 0,496 \\
SP & 765,126 & 1 & 765,126 & 6,013 & 0,015 \\
OJ & 56301,360 & 1 & 56301,360 & 442,453 & 0,000 \\
SP*OJ & 501,054 & 1 & 501,054 & 3,938 & 0,049 \\
Error & 18705,501 & 148 & 127,248 & & \\
Total & 527375,000 & 152 & & & \\
\hline Corrected Total & 76877,467 & 151 \\
\multicolumn{5}{c}{ a. R. Squared $=0,757$ (Adjusted R. Squared =0,750) } \\
\multicolumn{5}{c}{ Ket: SP (Social Pressure) and OJ (Organizational Justice) }
\end{tabular}

\section{Conclusion}

This study aims to provide empirical evidence by testing: (1) the influence of social pressures on the creation of budgetary slack by business unit controllers; (2) the influence of organizational justice in the form of procedural justice and distributive justice towards the creation of budgetary slack by business unit controllers; (3) the effect of interaction between social pressure and organizational justice on the creation of budgetary slack by business unit controllers; (4) Autonomous Motivation's influence on the interaction between social pressure and organizational justice towards the creation of budgetary slack by business unit controllers.

From the results of hypothesis testing that has been done, it is found that compared with low social pressures, high social pressure significantly makes the business units controller are more likely to create budgetary slack. The second finding, business unit controllers that receive organizational justice in the form of distributive justice are significantly more likely to create budgetary slack than if they get organizational justice in the form of procedural justice. A third finding, the tendency of business unit controllers to create a budgetary slack between receiving high social pressure and low social pressures proved significantly different at both levels of organizational justice. Furthermore, it is found that the tendency of business unit controllers to create a budgetary slack between receiving high social pressure and low social pressures proves to be significantly lower when business unit controlers gain organizational justice in the form of distributive justice than if they receive organizational justice in the form of procedural justice. The last founding is that Autonomous Motivation proved to have a significant influence on the interaction of relationships of social pressures and organizational justice on the creation of budgetary slack by business unit controllers.

This study has limitations, those are; manipulating tasks that do not include reward and punishment elements as in many other budgeting experiments, case scenarios and experimental procedures are presented and performed in the form of illustrations that simplify the real conditions in the field, and using students that are different from practitioners. Subsequent research can use participants who are direct actors in the budgeting process in companies that have business units. This study can also be expanded for example by looking at the tendencies of business unit controllers in budget negotiations or performance reporting. Personality factors other than Autonomous Motivation can be examined to trace its influence on the tendency of decision-making. 


\section{References}

[1] Ezkenazi, P. I., F. G. H. Hartmann, dan W. J. R. Rietdijk. 2016. Why Controllers Compromise on Their Fiduciary Duties: EEG Evidence on The Role of The Human Mirror Neuron System. Accounting, Organizations, and Society, 50: 41-50.

[2] Davis, Stan, F.T. Dezoort, dan L. S. Kopp. 2006. The Effect of Obedience Pressure and Perceived Responsibility on Management Accountants' Creation of Budgetary Slack. Behavioral Research in Accounting, 18: 19-36.

[3] Hartman, F. G. H. dan V. S. Mass. 2010. Why Business Unit Controllers Create Budget Slack: Involvement in Management, Social Pressure, and Machiavellianism. Behavioral Research in Accounting, 22(2): 27-49.

[4] Maas, V. S., dan Michal Matějka. 2009. Balancing the Dual Responsibilities of Business Unit Controllers: Field and Survey Evidence. The Accounting Review, 84(5): 1233-1253.

[5] Nasution, Damai dan Östermark. Ralf. 2012. The Impact Of Social Pressures, Locus Of Control, And Professional Commitment On Auditors' Judgment: Indonesian Evidence. Asian Review of Accounting, 20(2): 163-178.

[6] Langevin, P. dan C. Mendoza. 2010. How can Organizational justice moderate the unethical behaviors induced by budgeting systems?. Advances in Management Accounting, 11: 143-167.

[7] O'Boyle, E.H., Forsyth DR, Banks GC, dan McDaniel MA. 2012. A Meta-Analysis of the Dark Triad and Work Behavior: A Social Exchange Perspective. Journal Applied Psychology, 97(3): 557-579.

[8] Wakefield, Robin L. 2008. Accounting and Machiavellianism. Behavioral Research in Accounting, 20(1):115-129.

[9] Maiga, A. S. dan F. A. Jacobs. 2007. Budget Participation's Influence on Budget Slack: The Role of Fairness Perception, Trust and Goal Commitment. Journal of Applied Management Accounting Research, 5(1): 39-58.

[10] Özer, Gökhan dan Emine Yilmaz. 2011. Effects of Procedural Justice Perception, Budgetary Control Effectiveness and Ethical Work Climate on Propensity to Create Budgetary Slack. Business and Economics Research Journal, 4(2): 1-18.

[11] Nahartyo, Ertambang dan Intiyas Utami. 2014. Keeping Self-Interest under Control: Effects of Procedural Fairness and Project Success Rate in a Cost-Reduction Context. The Japanese Accounting Review, 4: 27-47.

[12] Wentzel, Kristin. 2004. Do Perceptions of Fairness Mitigate Managers' Use of Budgetray Slack During Asymmetric Information Condition?. Advances in Management Accounting, 13: 233-244.

[13] Umhpress, E. E., L. R. Ren, J. B. Bingham, dan C. I. Gogus. 2009. The Influence of Distributive Justice on Lying for and Stealing from a Supervisor. Journal of Business Ethics, 86: 507-518.

[14] Battiston, Pietro dan Simona Gamba. 2016. The Impact of Social Pressure on Tax Compliance: A Field Experiment. International Review of Law and Economics, 46: 78-85.

[15] Milgram, Stanley. 1963. Behavioral Study of Obedience. Journal of Abnormal and Social Psychology, 67: 371-378.

[16] Milgram, Stanley. 1965. Some Conditions of Obedience and Disobedience to Authority. Human Relations, 18: 57-76.

[17] Milgram, Stanley. 1974. Obedience to Authority. New York: Harper \& Row Publishers. 
[18] Yean, T. F. dan A. A. Yusof. 2016. Organizational Justice: A Conceptual Discussion. Social and Behavioral Sciences, 219: 798-803.

[19] Kusumawati, Yulia Tri. 2015. Pengaruh Perspektif Kebermanfaatan dan Tekanan Ketaatan Terhadap Penciptaan Slack Anggaran dengan Posisi Etika Individu Sebagai Variabel Pemoderasi. Tesis Gelar Master. Universitas Gadjah Mada.

[20] Dezoort, F. T. dan A. T. Lord. 1997. A Review and Synthesis of Pressure Effects Research in Accounting. Journal of Accounting Literature, 16: 28-85.

[21] Asch, S.E. 1956. Studies of Independence and Conformity: A Minority of One Against An Unanimous Majority. Psychological Monographs: General and Applied, 70(9): 1-70.

[22] Libby, Theresa. 2015. The Effect of Fairness in Contracting on The Creation Of Budgetary Slack. Advances in Accounting Behavioral Research, 6: 149-169.

[23] Lau, C. M. dan S. L. C. Tan. 2012. Budget Targets as Performance Measures: The Mediating Role of Participation and Procedural Fairness. Advances in Management Accounting, 20: 151-185.

[24] Hobson, Jessen L., M. J. Mellon, dan D. E. Stevens. 2011. Determinants of Moral Judgments Regarding Budgetary Slack:An Experimental Examination of Pay Scheme and Personal Values. Behavioral Research in Accounting, 23(1): 87-107.

[25] Sakalaki, M., C. Richardson, dan Y. Thepaut. 2007. Machiavellianism and Economic Opportunism. Journal of Applied Social Psychology 37: 1181-1190.

[26] Webb, R. A. 2002. The Impact of Reputation and Variance Investigations on the Creation of Budget Slack. Accounting, Organizations and Society, 27(4): 361-378.

[27] Greenberg, Jerald. 1987. A Taxonomy of Organizational Justice Theories. Academy of Management Review, 12(1): 9-22.

[28] Young, S. M. 1985. Participative Budgeting: The Effects of Risk Aversion and Asymmetric Information on Budgetary Slack. Journal of Accounting Research, 23(2): 829-842.

[29] Huang, Cheng-Li dan Mien-Ling Chen. 2010. Playing Devious Games, Budget-Emphasis in Performance Evaluation, and Attitudes Towards The Budgetary Process. Management Decision, 48(6): 940-951.

[30] Gago-Rodrigues, Susana dan David Naranjo-Gil. 2016. Effects of Trust and Distrust on Effort and Budgetary Slack: an Experiment. Management Decision, 54(8): 1908-1928. 